\title{
A Trait-Based Approach to National Origin Claims Under Title VII
}

The current approach to the enforcement of Title VII ${ }^{1}$ renders its prohibition against national origin discrimination ${ }^{2}$ virtually meaningless for the culturally unassimilated. It permits an employer to reject qualified applicants of a particular national origin as long as he hires more assimilated applicants of the same origin instead. ${ }^{3}$ Yet a refusal to hire because of cultural characteristics or traits is nothing less than discrimination on the basis of national origin. As it is now enforced, Title VII cannot keep its promise of individual equality; it actually perpetuates discrimination against the least assimilated members of a national origin group.

Courts should consider the heterogeneity that exists within a single national origin group in their treatment of national origin cases under Title VII. Such an approach better achieves Title VII's goal of individual protection and eliminates the denigration of cultural identity implicit in today's enforcement of the statute.

1. Title VII of the Civil Rights Act of 1964,42 U.S.C. $\$ \S 2000 \mathrm{e}$ to $2000 \mathrm{e}-17$ (1982).

2. Section 703(a) states in pertinent part:

It shall be an unlawful employment practice for an employer-

(1) to fail or refuse to hire or to discharge any individual or otherwise to discriminate against any individual . . . because of such individual's . . national origin; or

(2) to limit, segregate, or classify his employees or applicants for employment in any way which would deprive or tend to deprive any individual of employment opportunities . . . because of such individual's ... national origin.

42 U.S.C. $\S 2000 \mathrm{e}-2(\mathrm{a})$ (1982).

3. Under the current approach to national origin discrimination, the employer who intentionally discriminates among applicants on the basis of national origin-linked characteristics is generally held to have violated Title VII. See infra note 27 (cases cited therein) and accompanying text. Still, an employer might offer the hiring of one national origin group member to rebut or preclude an inference of discriminatory motive with respect to another. See infra note 29 and accompanying text. Further, discriminatory intent is often difficult to prove or lacking altogether. See Fiss, $A$ Theory of Fair Employment Laws, 38 U. CHI. L. REv. 235, 266 (1971) ("[A]n admission [of racial discrimination] is, of course, unlikely, especially where social mores disapprove of the conduct prohibited by the law."); see also Untred States Comm'N on Civil. Rights, AfFirmative Action In the 1980s: Dismantling the Process of Discrimination 8 (1981) ("Although open and intentional prejudice persists, individual discriminatory conduct is often hidden and sometimes unintentional.") (footnote omitted).

The Equal Employment Opportunity Commission (EEOC) Guidelines on Discrimination Because of National Origin, 29 C.F.R. $\$ 1606.1$ (1984), define "national origin discrimination . . . as including . . . the denial of equal employment opportunity because ... an individual has the physical, cultural or linguistic characteristics of a national origin group." That the EEOC is unwilling to apply a trait-based approach to all national origin discrimination is suggested by its further regulatory pronouncement that the use of certain characteristics as qualifying screens is not to be considered an exception to the "bottom line" rule (discussed infra notes 36-45 and accompanying text). See 29 C.F.R. § 1606.6(b) (1984). 


\section{Recognizing Trait-Based Discrimination}

Discrimination begins with an attachment of arbitrary or extraordinary significance to human differences. ${ }^{4}$ Gurrent enforcement of Title VII suggests that national origin discrimination in the workplace arises from employer antipathy (both conscious and unconscious) toward the mere fact of an applicant's ancestry. Yet such a view of national origin discrimination is blind to the real nature of prejudice. Differences in dress, language, accent, and custom associated with a non-American origin are more likely to elicit prejudicial attitudes than the fact of the origin itself. ${ }^{5}$ Although Americans might celebrate the diversity of their ancestral origins, ${ }^{6}$ they are apt to be less accepting of the traits characteristic of those origins.

Thus, not all people of the same ancestral origin are equally vulnerable to national origin discrimination. The exclusive focus upon ancestral origin in Title VII national origin cases ignores this reality. In De Volld $v$. Bailar, ${ }^{7}$ for example, the Fifth Circuit summarily dismissed a MexicanAmerican's ${ }^{B}$ claim of national origin discrimination where the Civil Service promotion she sought went to another Mexican-American employee. "[W]hatever motives the Givil Service Commission may have had in

4. See Hesburgh, Foreword in PREjudice U.S.A. vi (C. Glock \& E. Siegelman eds. 1969): "Prejudice begins because of a perception of difference-difference of color, language, religion, social or economic situation, physical appearance, even sex. We follow this perception of difference with an evaluation and a comparison: What we have or are is the best, so anything different must be inferior."

5. The very title of Andrew Greeley's book about ethnicity and ethnic relations, WHY CAN'T They Be Like Us? AMerics's WhITe Ethinic Groups (1970), is illuminating in this regard. It would be hard to imagine anyone asking, "Why can't they have been from the same place as we?" To characterize the phenomenon another way, people are generally more concerned with how they differ from someone today rather than yesterday. An individual's speech, dress, and mannerisms are his present; his ancestral origin is his past. Only through the medium of characteristics does ancestral origin become apparent in the present.

Even the employer whose animus is directed at ancestral origin per se might rely upon national origin-linked characteristics to give effect to his feelings. Given a clear statutory prohibition against discrimination on the basis of national origin, he is unlikely to question job applicants directly about their ancestry. See Fiss, supra note 3 , at 266 . Instead, he might discern an applicant's nationality on the basis of proxies such as surname, accent, dress, or any number of other traits that identify a particular ancestral origin. Thus, an implicit "no Mexican-Americans allowed" rule might be administered through a selection process focusing on characteristic manifestations of Mexican origin, such as a Spanish accent.

An employer prejudiced against an ancestral origin per se who is forced to choose among applicants of that origin may well rely on distinctively foreign characteristics in more than an administrative way. Given a choice between two equally qualified Americans of Mexican ancestry, the employer would probably favor (perhaps consciously and perhaps not) the one who was more assimilated.

6. Walt Whitman proudly called his country a "nation of many nations." W. WHITMan, Song of Myself, in Leaves of Grass 40 (M. Cowley ed. 1959). President Franklin Roosevelt once reminded us that "all of our people all over the country, all except the pure-blooded Indians, are immigrants, or descendants of immigrants, including even those who came over here on the Mayflower." N.Y. Times, Nov. 5,1944 , at 38 , col. 2 (campaign address).

7. 568 F.2d 1162 (5th Cir. 1978).

8. Most of the examples and cases furnished in this Note are concerned with discrimination against Hispanics. The arguments set forth here are equally applicable to discrimination against other national groups. 
choosing between two people of the same ethnic origin," the court concluded, "discrimination cannot have been among them." But insofar as the court focused solely on ancestral origin, it may have permitted the employer to exercise a preference for one individual over another simply because the former was more assimilated. ${ }^{10}$ And an employer who does so has discriminated on the basis of national origin.

In allowing employers to satisfy their statutory obligation by hiring any individual or individuals of a particular ancestral origin, courts permit discrimination to persist. Most employers are naturally inclined to hire applicants who are "like" them over those who are not; absent judicial cognizance of that fact, Title VII becomes a statute which, at best, coerces job applicants to assimilate and, at worst, keeps them jobless. ${ }^{11}$

Courts should therefore employ a definition of national origin discrimination which includes the concept of discrimination on the basis of national origin-linked (i.e., cultural) traits. ${ }^{12}$ Under such a trait-based approach, an individual's employment opportunities would not be limited, as

9. 568 F.2d at 1165. The court also stated: "Any unfairness in the choice between the plaintiff and [the promotion recipient] cannot have had its source in discrimination based on national origin; this being so, there is no Title VII action." Id.

10. The Fifth Gircuit should have been especially wary of this possibility given the Civil Service Commission's prior determination that the defendant had initially passed over both MexicanAmerican clerks for promotion because of their national origin. 568 F.2d at 1163. See supra note 5 (employer prejudiced against national origin group per se likely to choose more assimilated of two individuals from that group).

11. Inasmuch as some national origin-linked characteristics are immutable, the unassimilated group member may face an absolute barrier to job opportunity rather than coercive pressure to assimilate. A Mexican immigrant who has learned English upon his arrival in America may find it nearly impossible to discard his Spanish accent. See Carino v. University of Oklahoma, 25 Fair Empl. Prac. Cas. (BNA) 1332, 1337 (W.D. Okla. 1981) (accent not easily changed for foreign-born person who had lived abroad for long time), affd, 750 F.2d 815 (10th Cir. 1984). Hiring decisions that for no legitimate business reason depend on accent discriminate on the basis of an immutable trait in the same way that race-based segregation does.

12. Judicial acceptance of plaintiff classes not limited to individuals of a single ancestral origin may be taken at least as an indication of receptiveness to the notion of trait-based discrimination. If courts were concerned exclusively with discrimination directed at ancestral origin, they might insist that plaintiffs and plaintiff classes define themselves as "Mexican-Americans," "Cuban-Americans," etc., and that they segregate their claims along those lines. Implicit in the grouping of plaintiffs from various origins into composite categories like "Hispanic," "Spanish language," and "Spanishsurnamed," see, e.g., Lasso v. Woodmen of the World Life Ins. Co., 741 F.2d 1241 (10th Cir. 1984) (case remanded for determination of whether defendant's hiring policies discriminate against Hispanics); Bushey v. New York State Civil Serv. Comm'n, 733 F.2d 220 (2d Cir. 1984) (same), cert. denied, 105 S. Ct. 803 (1985); Craig v. County of Los Angeles, 626 F.2d 659, 661 n.1 (9th Cir. 1980) (plaintiff class defined by district court as "Spanish-surnamed" or "Spanish language" persons), cert. denied, 450 U.S. 919 (1981); EEOC v. Navajo Refining Co., 593 F.2d 988 (10th Cir. 1979) (disparate impact claim brought by Spanish-surnamed Americans); EEOC v. Datapoint Corp., 570 F.2d 1264 (5th Cir. 1978) (disparate treatment class action brought on behalf of Spanishsurnamed people), may be an assumption that such individuals have common characteristics that cross national lines, and that make them similarly vulnerable to discriminatory employment practices. The fact that such characteristics are national origin-linked means that discrimination on that basis is national origin discrimination. This Note would not bar the grouping of plaintiffs of different ancestral origins. Indeed, it would support the grouping of such plaintiffs where they are similarly unassimilated. Courts that do approve the grouping of different ancestral origins should be particularly 
they are now, by non-job-related personal characteristics that manifest cultural identity. ${ }^{13}$ The law would recognize that employers might draw distinctions, not just among individuals of different ancestral origins, but also among individuals of the same ancestral origin.

Current enforcement of the Age Discrimination in Employment Act of $1967^{14}$ reflects such an enlightened understanding of group heterogeneity. The statute defines a specially protected category of individuals, ages forty through sixty-nine. ${ }^{15}$ Any employer who fires all of his sixty-nine year-old employees and replaces them with forty year-olds, simply because the latter are younger, does not diminish the representation of the protected category in his work force; nevertheless, he displaces the older members of the group solely because of the extent to which they possess the trait being protected-age. Accordingly, the courts have held it a violation of the Act to choose between two individuals on the basis of their age, even when both are within the protected group. ${ }^{16}$

Each national origin group is similarly heterogeneous. There are the "forty year-olds"-fifth generation Americans who are completely assimilated-and the "sixty-nine year-olds"-immigrants of the same origin who speak and dress in a distinctly foreign manner. Between them are the many shades of grey. Under the ADEA, each shade is perceptibly distinct; we know that forty-five year-olds are older (and thus, generally more susceptible to age discrimination) than forty year-olds. Under Title VII's prohibition against discrimination on the basis of national origin, however, there are no such clear demarcations; we cannot measure assimilation in precise units. Yet imprecision in measurability cannot justify neglect of the real differences among individuals and the real discrimination

careful in ensuring that the broader group (e.g., "Hispanic") does not include ancestral origin groups of different degrees of assimilation.

13. Accent and skin pigmentation are among the most obvious examples of national origin-linked characteristics. Others include those over which the applicant arguably has more control, such as surname, knowledge of American history, table manners, personal appearance (i.e., dress and hair styles), etc. The trait-based approach would cover discrimination on the basis of mutable as well as immutable characteristics. See infra text accompanying notes 56-61.

14. Pub. L. No. $90-202,81$ Stat. 602 (codified as amended at 29 U.S.C. $\$ \S 621-34$ (1982)) [hereinafter cited as ADEA].

15. 29 U.S.C. $\S 631$ (a) (1982).

16. See, e.g., McCorstin v. U.S. Steel Corp., 621 F.2d 749, 754 (5th Cir. 1980) (plaintiff need not be replaced by someone under age 40 to establish prima facie case); Loeb v. Textron, Inc., 600 F.2d 1003, 1013 n.9 (1st Cir. 1979) (replacement of 60 year-old by 35 year-old or even 45 year-old within protected class more suggestive of discrimination than replacement of 45 year-old by 39 year-old outside it); Moore v. Sears, Roebuck \& Co., 464 F. Supp. 357, 361 (N.D. Ga. 1979) (replacement of employees by other members of protected class does not constitute evidence by which defendant can conclusively rebut prima facie showing of age discrimination); Polstorff v. Fletcher, 452 F. Supp. 17, 24 (N.D. Ala. 1978) (replacement by person outside "protected group" not necessary to establish prima facie case); see also 29 C.F.R. \$ 1625.2(a) (1984) ("It is unlawful . . . for an employer to discriminate in hiring . . . by giving preference because of age between individuals within the [protected] age bracket."). 
suffered by the least assimilated of those individuals. To treat the national origin group as a uniform, singular entity is to deny the force of Title VII's antidiscrimination protection to those who need it most.

This is not to suggest, however, that an applicant's lack of assimilation-or more accurately, its characteristic manifestations-can never justify an employer's adverse hiring decision. ${ }^{17}$ A Mexican-American who possesses a strong Spanish accent is probably not suited for a position as a speech therapist. ${ }^{18}$ The trait-based approach to national origin discrimination does not command that he be hired anyway. ${ }^{19}$ It suggests only that if he is denied a job oportunity because of his accent, the denial should be grounded in a legitimate business concern ${ }^{20}$ rather than in prejudice against people who possess traits characteristic of Mexican origin.

17. Similarly, an employer may have a legitimate reason for hiring a 40 year-old instead of a 69 year-old. See ADEA $\S 4(f), 29$ U.S.C. $\$ 623(f)$ (1982) (setting forth business-related defenses for employer charged with age discrimination).

18. It may be argued, however, that our conception of what makes a job-seeker qualified is itself ethnocentric. While the example of a speech therapist may be unimpeachable on this ground, avowed job qualifications are often themselves the product of social construction. In Diaz v. Pan American World Airways, 442 F.2d 385 (5th Cir.), cert. denied, 404 U.S. 950 (1971), a male applicant for a flight attendant position was rejected because the airline would not hire a man; women were thought to be better at the "non-mechanical aspects of the job," 442 F.2d at 387, such as serving and reassuring anxious passengers. Sex, the airline argued, was a bona fide occupational qualification (BFOQ). See infra note 20 . The Fifth Circuit disagreed on the ground that such customer preference reflected the "very prejudices [Title VII] was meant to overcome." 442 F.2d at 389. The extent to which anxious passengers of both sexes are more receptive to the nurturance and support of women may reflect the social conditioning of a sexist world. See C. MacKinnon, Sexual Harassment of Working WoMen 178-82 (1979) (discussing Diaz and sexual role-typing). This argument has been cast in more general terms. According to one commentator, "[T]he goal of sexual equality [has been] to create a world in which persons of both genders are encouraged to act as men . . . ." Note, Toward a Redefinition of Sexual Equality, 95 HARv. L. REv. 487, 487 (1981). Implicit in a concept of sexual equality that adopts traditional male roles is an arguably sexist presumption that male roles are the more desirable. See id. at 506. Similarly, the equality offered by the trait-based approach may be an equality viewed through an ethnocentric lens. A more radical restructuring of Title VII is beyond the scope of this Note, however. See infra notes 19 \& 63 (trait-based approach would preserve present notions of business necessity).

19. In this respect, the trait-based approach leaves undisturbed the currently accepted conception of Title VII's antidiscrimination goals. As the Court stated in Griggs v. Duke Power Co., 401 U.S. 424, 430-31 (1971), "Congress did not intend by Title VII . . . to guarantee a job to every person regardless of qualifications. In short, the Act does not command that any person be hired simply because he was formerly the subject of discrimination, or because he is a member of a minority group."

20. Under $\S 703(\mathrm{e})$ of Title VII, 42 U.S.C. $\S 2000 \mathrm{e}-2(\mathrm{e})(1)(1982)$, the employer may invoke the defense of a bona fide occupational qualification (BFOQ) to justify explicit national origin discrimination. As applied to the trait-based approach, the BFOQ defense would permit the employer to hire on the basis of a national origin-linked characteristic where such a characteristic was "reasonably necessary to the normal operation" of the employer's business. Id. The employer may defend against a showing of adverse effect by dernonstrating the "business necessity" of the disputed employment practice-i.e., by showing the practice "to be necessary to safe and efficient job performance." Dothard v. Rawlinson, 433 U.S. 321, 332 n.14 (1977). The employer would be entitled to make such a demonstration under the trait-based approach as well. 


\section{Applying the Trait-Based ApProach Under Title VII}

A Title VII discrimination claim may proceed under either of two different theories of liability that together promote the equality objective of Title VII. In the "disparate treatment" case, "[p]roof of discriminatory motive is critical."21 The plaintiff must demonstrate the employer's intent to discriminate on the basis of race, color, religion, sex, or national origin. In the "disparate impact" case, "[p]roof of discriminatory motive . . . is not required."22 The plaintiff may prevail simply by establishing the adverse effect of a particular employee selection device upon the protected group to which he belongs. The disparate impact theory envisions "the removal of artificial, arbitrary, and unnecessary barriers to employment" maintained by facially neutral practices. ${ }^{23}$

Judicial acceptance of the trait-based approach would expand considerably the scope of an employer's potential liability in both kinds of cases. This expansion is nevertheless consistent with the language and purpose of Title VII. Because the basic prohibitory provisions of the statute are cast in general terms and do not provide a precise definition of national origin discrimination, ${ }^{24}$ the courts are not bound by its text to the current conception of national origin discrimination. Nor are they bound to that conception by congressional intent: No legislative debate or committee report concerned with Title VII directly addressed the issue of what constitutes discrimination on the basis of national origin. ${ }^{25}$ Further, the term

21. International Bhd. of Teamsters v. United States, 431 U.S. 324, 335 n.15 (1977). In McDonnell Douglas Corp. v. Green, 411 U.S. 792, 802-04 (1973), the Supreme Court set forth a tripartite order and allocation of proof for determining whether such a motive exists. First, the plaintiff must establish a prima facie case (see infra note 28 and accompanying text). It is then up to the employer "to articulate some legitimate, nondiscriminatory reason" for his actions. 411 U.S. at 802 . Finally, the plaintiff has an opportunity to show that any such stated reason is in fact a "pretext," id. at 804 , to mask an illegal motive.

22. Teamsters, 431 U.S. at 336 n.15. Albemarle Paper Co. v. Moody, 422 U.S. 405, 425 (1975), defined a tripartite order and allocation of proof for disparate impact cases. The plaintiff makes out a prima facie case by showing that the employer's selection device has a substantially adverse impact on his protected group. The burden then shifts to the employer to show that this impact is the result of a "business necessity" (see supra note 20). If the employer can demonstrate such a relationship between the challenged employment practice and the job in question, it remains open to the plaintiff to show that "other ... selection devices, without a similarly undesirable . . . effect, would also serve the employer's legitimate interest[s]." Id.

23. Griggs v. Duke Power Co., 401 U.S. 424, 431 (1971).

24. See supra note 2 (quoting $\S 703(\mathrm{a})$ ). The EEOC Guidelines on Discrimination Because of National Origin, 29 C.F.R. $\$ \S 1606.1-.8$ (1984), nominally adopt a trait-based approach. See supra note 3.

25. Title VII's legislative history is "quite meager in this respect." Espinoza v. Farah Mfg. Co., 414 U.S. 86, 88-89 (1973). "The only direct definition given the phrase "national origin," was precipitated because a clerical error caused the words to be deleted from the House version of the bill. Id. at 89. Congressman Roosevelt, Chairman of the House Subcommittee that reported the bill, explained to his colleagues that " 'national origin' means national. It means the country from which you or your forebears came from." 110 CoNG. REC. 2549 (1964). But what constitutes national origin discrimination? The history of the statute is silent on the subject. See UNITED STATES EQUal EMPLOYMENT Opportunity Comm'n, Legislative History of TtTles VII aNd XI of Givil. Rights ACT of 
"national origin" was used infrequently prior to the adoption of Title VII ${ }^{26}$ thus, the statute did not incorporate a previously accepted definition of the term. Given the consistency of the trait-based approach to national origin discrimination with Title VII's ultimate aim of individual equality, the courts should adopt that approach in the adjudication of disparate treatment and disparate impact claims.

\section{A. Disparate Treatment}

Under the current approach to national origin discrimination, the victim of intentional trait-based discrimination is generally entitled to relief. ${ }^{27}$ Plaintiff's proof of (i) his membership in a protected group, (ii) his application and qualification for the job, (iii) his rejection by the employer and (iv) the employer's continued consideration of applicants with similar qualifications, establishes a prima facie case, ${ }^{28}$ whether the plaintiff's rejection was grounded in group membership per se or in traits associated with that membership. In some cases, however, an employer has been able

1964 (1968).

26. The Civil Rights Act of 1964 was the first federal statute specifically prohibiting discrimination because of "national origin." The 1964 statute uses "national origin" in all substantive provisions except Title I-Voting. The use of those specific words in federal law appeared for the first time in the 1957 Civil Rights Act, Pub. L. No. 85-315, § 104(a)(1), 71 Stat. 634, 635 (1957) (current version at 42 U.S.C. $\$ 1975$ c (1982)). Section 104(a)(1) imposed on the newly created Civil Rights Commission the duty to "investigate allegations . . . that certain citizens . . . [were] being deprived of their right to vote . . . by reason of their color, race, religion, or national origin . . . "Id. No other civil rights act used the words "national origin."

In the administrative law context, the words "national origin" first appeared in President Roosevelt's landmark Executive Order No. 6802, 6 Fed. Reg. 3109 (1941), which established the first Committee on Fair Employment Practice. The order applied not only to government employment but to all defense contracts and to vocational and training programs administered by federal agencies. The policy against discrimination in employment on the basis of "national origin" was continued through a succession of executive orders, culminating in President Kennedy's Executive Order No. 10925, 26 Fed. Reg. 1977 (1961), which established the President's Committee on Equal Employment Opportunity. The preamble of the order reads in pertinent part: "Whereas discrimination because of race, creed, or national origin is contrary to the Constitutional principles and policies of the United States ...."Id. at 1977.

27. See, e.g., Berke v. Ohio Dep't of Pub. Welfare, 628 F.2d 980 (6th Cir. 1980) (denial of position due to Polish accent held to constitute national origin discrimination); Carino v. University of Oklahoma, 25 Fair Empl. Prac. Cas. (BNA) 1332 (W.D. Okla. 1981) (University's demotion of plaintiff because of Philippine accent held unlawful), affd, 750 F.2d 815, 819 (10th Cir. 1984); EEOC Dec. AL 68-1-155E, 1 Fair Empl. Prac. Cas. (BNA) 921 (1969) (evidence of refusal to consider applicant because of accent reasonable basis for finding Title VII violation). See also B. Schlei \& P. Grossman, Employment Discrimination Law 290 (2d ed. 1983) (discrimination on basis of immutable characteristic associated with race violates Title VII under disparate treatment theory, even though not all members of race share characteristic); EEOC Dec. 7090, 2 Fair Empl. Prac. Cas. (BNA) 236 (1969) (Title VII violation found where black stewardess applying for job noted to have "broad nose" and "large lips").

28. These elements of the prima facie case are set forth in McDonnell Douglas Corp. v. Green, 411 U.S. 792, 802 (1973). 
to put forward his hiring of another group member to rebut or even preclude the inference of discriminatory motive in refusing to hire the plaintiff. ${ }^{29}$ Such cases stand firmly opposed to Title VII's promise of individual protection, as reflected in both its text and legislative history. Section 703(a)(1) prohibits discrimination "against any individual"; section 703(a)(2) prohibits practices which "deprive or tend to deprive any individual of employment opportunities."so Senators Clark and Case, bipartisan floor managers of the 1964 Civil Rights Act, submitted to the Senate an interpretive memorandum stating:

[D]iscrimination is prohibited as to any individual. While the presence or absence of other members of the same minority group in the work force may be a relevant factor in determining whether in a given case a decision to hire or to refuse to hire was based on race, color, etc., it is only one factor and the question in each case would be whether that individual was discriminated against. ${ }^{31}$

The trait-based approach better accords with this vision of Title VII. In a case like $D e$ Volld $v$. Bailar, ${ }^{32}$ the defendant employer should not be able to insulate himself from liability for discriminating against one MexicanAmerican simply by promoting another. Disparate treatment is disparate treatment, no matter who reaps its benefits.

Courts have upheld this vision of Title VII in cases involving discrimination on the basis of race and sex. In Reeb $v$. Marshall, ${ }^{33}$ the Eighth Circuit concluded that a plaintiff discharged because of her "failure to conform to her supervisor's stereotype of a professional woman" could prevail under Title VII's disparate treatment theory, even though she was replaced by another woman. ${ }^{34}$ And in an action brought by the EEOC, a court determined that the selection of a light-skinned, caucasian-featured black applicant over a qualified but dark-skinned, black-featured one was actionable. ${ }^{36}$ The same logic that has informed disparate treatment analysis in such race and sex cases should be applied in national origin cases as well.

29. See De Volld v. Bailar, 568 F.2d 1162 (5th Cir. 1978) (discussed supra notes 7-10 and accompanying text); $c f$. Malarkey v. Texaco, 559 F. Supp. 117 (S.D.N.Y. 1982) (female plaintiff passed over for promotion given to other females cannot have been victim of sex discrimination), aff $d$, 704 F.2d 674 (2d Cir. 1983).

30. 42 U.S.C. $\$ 2000 \mathrm{e}-2$ (a) (1982) (emphasis added).

31. 110 Cong. REC. 7213 (1964) (emphasis added).

32. 568 F.2d 1162 (5th Cir. 1978). See supra notes 7-10 and accompanying text.

33. 626 F.2d 43 (8th Cir. 1980).

34. Id. at 46. But see Malarkey v. Texaco, 559 F. Supp. 117 (S.D.N.Y. 1982), affd, 704 F.2d 674 (2d Cir. 1983) (described supra note 29).

35. EEOC Dec. 72-0454 (Sept. 15, 1971) (reported in B. SCHLEI \& P. Grossman, supra note 27 , at 290 n.3). 


\section{B. Disparate Impact}

An employer whose selection criteria, taken separately and together, have no adverse impact upon a given national origin group, is presently safe from the disparate impact claims of rejected group members. ${ }^{36}$ Yet a selection process, or even a single selection criterion, that results in group parity may still have an adverse impact on the least assimilated individuals in that group. ${ }^{37}$ While no court has recognized the disparate impact claim of a "subgroup" defined by national origin-linked traits, ${ }^{38}$ the Supreme Court's reasoning in Connecticut $v$. Teal ${ }^{39}$ implicitly supports such a claim. Teal affirmed Title VII's role in protecting individuals from employment discrimination under even the group-oriented disparate impact theory. The Court rejected Connecticut's $s^{40}$ assertion that the "bottom line" of its selection process-the proportional representation of blacks among promotion recipients-immunized it from liability for the adverse impact of a particular promotion criterion. ${ }^{41}$ Citing the statute's

36. Indeed, the EEOC will not sustain a disparate impact claim made out with respect to certain criteria of selection where the selection process as a whole (i.e., the "bottom line") produces no adverse impact upon the relevant national origin group. For example, "the Commission does not consider . . . the denial of employment opportunities because of an individual's foreign accent . . . to be [an] exception[ ] to the 'bottom line' concept . . . ." 29 C.F.R. § 1606.6(b). Under the trait-based approach, a disparate impact claim based on a single criterion of the selection process would not be trumped by the lack of an adverse impact at the "bottom line." Further, disparate impact claims based on either the "bottom line" or a single criterion would be sustained even when adverse impact upon the relevant national origin group was negligible, if the complaining party were able to demonstrate an adverse impact upon the least assimilated individuals of the relevant group.

37. See supra note 5 and text accompanying note 11 . One scholar has pointed out that a selection process which results in group parity for both blacks and women may still have an adverse effect upon the subgroup of individuals defined by their membership in both protected categories. She advocates the use of disparate impact analysis for such "compound discrimination" cases. Shoben, Compound Discrimination: The Interaction of Race and Sex in Employment Discrimination, 55 N.Y.U. L. REV. 793 (1980). This Note supports the use of subgroups formed not by the intersection of two protected groups, but rather, by the division of a single protected group on the basis of traits characteristic of group membership.

38. The Mexican-American Legal Defense \& Education Fund (MALDEF) apparently has never even attempted to make out a disparate impact claim on behalf of a subgroup of Mexican-Americans who share similar national origin-linked traits where disparate impact with respect to the whole group of Mexican-Americans was lacking. Telephone interview with Joaquin G. Avila, President \& General Counsel, MALDEF (Feb. 14, 1984) and with Morris J. Baller, Vice President, Legal Programs, MALDEF (March 7, 1984).

39. 457 U.S. 440 (1982).

40. In 1972, Title VII's coverage was extended to prohibit employment discrimination by "governments, governmental agencies, and political subdivisions." Pub. L. No. 92-261, § 2, 86 Stat. 103, 103 (1972) (codified as amended at $\S 701$ (a), 42 U.S.C. $\$ 2000 \mathrm{e}(\mathrm{a})(1982)$ ).

41. 457 U.S. at 451-52. The dissenters in Teal charged that the majority's repudiation of the "bottom line" principle was "inconsistent with the very nature of disparate-impact claims." Id. at 456 (Powell, J., dissenting). Disparate impact theory, by definition, focuses on groups, and attempts to achieve equality through enhanced group opportunity. Id. at $459-60$. But it is unfair to extract from this limitation in the means of achieving equality a restricted scope of the ultimate equality to be achieved. Even the dissenters agreed that the aim of Title VII is to protect individuals rather than groups. Id. at 458; see also Case Note, The Bottom Line Concept Under Title VII: Connecticut v. Teal, 24 B.C.L. REv. 1131, 1172 (1983) ("The Teal majority correctly recognized that the individual is to be the focus of the protection offered by Title VII."). But see Blumrosen, The Group Interest 
language ${ }^{42}$ as well as its legislative history, ${ }^{43}$ the Court concluded that "Title VII strives to achieve equality of opportunity by rooting out . . . [employment practices] that have a discriminatory impact upon individuals."14 Thus, the overall proportionality of Connecticut's selection process could not vindicate the use of a non-job-related test which eliminated a subgroup of black individuals from the promotion competition. The same analysis applies with equal force to a single criterion of the selection process: A proportional outcome should not be allowed to mask the discriminatory impact of even one selection criterion upon a subgroup of individuals defined by their possession of group-linked characteristics. The traitbased approach is essential to rooting out employment practices that discriminate against the least assimilated individuals of a national origin group solely because of the extent to which they possess the traits characteristic of group membership. ${ }^{45}$

Intra-group heterogeneity makes deceptive the use of the national origin group as a benchmark for statistical comparison; such a benchmark can disguise real differences in job opportunity among individuals within that broad category. Under current law, for example, if an applicant pool and

Concept, Employment Discrimination, and Legislative Intent: The Fallacy of Connecticut v. Teal, 20 HARv. J. ON LEGIS. 99, 103 (1983) ("One reason for the Court's error in Teal . . . is the difficulty in giving concrete reality to the fundamental purpose of the Civil Rights Act: to enhance the status of minorities as groups in American society.") (emphasis in original). The necessarily group-oriented approach of adverse impact theory should be tailored, as much as possible, to the achievement of individual equality.

42. The Court pointed particularly to the repeated use of the word "individual" in $\S 703$ (a)(2) (see supra text accompanying note 30 ). 457 U.S. at 453-54.

43. The Court remarked that Title VII's legislative history is "replete with references to protection for the individual employee." 457 U.S. at 454. The opinion cited the Clark-Case memorandum, quoted supra text accompanying note 31 , and the following comment made by Senator Williams: "Every man must be judged according to his ability. In that respect, all men are to have an equal opportunity to be considered for a particular job." 110 CoNG. REC. 8921 (1964). One of the bill's major proponents, Senator Humphrey, told his colleagues: "[T]he issue here is not how many people are employed. The issue is whether a man shall be denied the opportunity to be employed on the basis of his merit ...."Id. at 13084.

44. 457 U.S. at 451. The Court's decision in City of Los Angeles Dep't of Water \& Power v. Manhart, 435 U.S. 702 (1978), reflects a similar concern for individual, as opposed to group, opportunity. The case presented a Title VII-based challenge to employer-administered pension plans that required larger contributions from women than from men because the former, as a group, live longer. The Court posed the issue as "whether the existence or nonexistence of 'discrimination' is to be determined by comparison of class characteristics or individual characteristics." Id. at 708. It concluded that the basic policy of Title VII "requires [a] focus on fairness to individuals rather than fairness to classes." Id. at 709. Accord, Arizona Governing Committee v. Norris, 463 U.S. 1073 (1983) (women may not be paid lower monthly pension benefits than men who have made same contributions simply because women, as a class, outlive men).

45. The trait-based approach would apply the force of Teal's analysis beyond the framework of Teal itself. In Teal, the Court sustained a challenge to a single component of the employer's selection process that had an adverse impact upon a protected group. Under the trait-based approach, the courts would sustain not only a challenge to a single component of the selection process that had an adverse impact upon a national group, but also a challenge to a single component of the selection process that had an adverse impact upon the least assimilated individuals of that group. Currently, the EEOC will not sustain either type of challenge. See supra note 36. 
work force were made up entirely of Mexican-Americans, the rejected applicants could not establish a prima facie disparate impact case ${ }^{\mathbf{4}}$ no matter how culturally skewed the employer's selection device. And yet, the individuals with strong cultural identities might still have been the victims of national origin discrimination.

Under the trait-based approach to national origin discrimination, the broad group of Mexican-Americans would not necessarily be the benchmark for statistical comparison. Ideally, the benchmark would correspond, as closely as possible, to the claimant's level of cultural assimilation-i.e., the extent to which he possesses national origin-linked characteristics. For the qualified Mexican-American who is only minimally assimilated, the benchmark for statistical comparison would be those qualified applicants and job-holders who are similarly unassimilated. Courts would compare the success rate of the applicant pool not to the success rate of the entire group of Mexican-Americans, but to the success rate of the subgroup to which the claimant belongs. ${ }^{47}$ Similarly, courts would compare the representation of that particular subgroup in the employer's work force with its representation in the relevant population, rather than comparing the representation of the entire group of Mexican-Americans in the employer's work force with its representation in the relevant population. ${ }^{48}$

To be sure, the delineation of such subgroups may prove complicated. Unlike the single criterion of year of birth that courts might use to identify subgroups within the ADEA's protected category of forty to sixty-nine year-olds, ${ }^{49}$ no single criterion measures so precisely the different degrees of assimilation under the trait-based approach to national origin discrimination. The distinction between Mexican-Americans and non-MexicanAmericans rests on an objective characteristic-ancestry. The distinction between more and less assimilated Mexican-Americans is not as readily apparent.

There are indirect (if imperfect) ways, however, to measure the extent of an individual's assimilation. Courts might focus their attention on a single criterion-the primary language spoken in each applicant's home,

46. See supra note 22 (summarizing tripartite order and allocation of proof in disparate impact case).

47. This form of proof is called a "pass/fail" comparison. See B. Schlei \& P. Grossman, supra note 27, at 1333-34. In Griggs v. Duke Power Co., 401 U.S. 424, 430 n.6 (1971), the plaintiff satisfied his prima facie burden by demonstrating a substantial disparity between the percentage of potential black applicants who could meet the challenged employment requirement of a high school diploma and the percentage of potential white applicanis who could do the same.

48. The plaintiffs in International Bhd. of Teamsters v. United States, 431 U.S. 324, 337-38 (1977), relied in part upon this form of statistical proof, called a "population/work force" comparison. See B. Schlei \& P. Grossman, supra note 27, at 1334. The gross disparity in the percentage of black employees and the percentage of black applicants was sufficient to meet the requirements of a prima facie case.

49. See supra notes $14-16$ and accompanying text. 
for example ${ }^{80}$-and use that criterion as a proxy for the degree of an individual's assimilation. ${ }^{51}$ Americans of Hispanic origin who speak English at home are apt to be more assimilated than those who do not. Therefore, an Hispanic plaintiff who speaks Spanish at home might properly rely upon statistical comparisons that use as benchmarks the selection success rate or work force representation of only those Hispanics who speak Spanish at home. ${ }^{52}$ One court has used a series of proxies, including primary language and level of education, to distinguish subgroups of Hispanics in a section 1983 action. $^{\text {.3 }}$

Of course, no proxy is perfect. Hispanics who speak Spanish at home, for example, are not all unassimilated to the same degree, just as Hispanics who speak English at home are not all assimilated to the same degree.

50. Once courts become familiar with the trait-based approach to national origin discrimination, they might allow plaintiffs to construct adverse impact claims with reference to subgroups that are differently defined. One could argue, for example, that first generation Americans are less assimilated than second and third generation Americans of similar origin. See T. SowELL, EThNic AMERICA: A HISTORY 262 (1981) (first generation Mexican-Americans earn 20\% less than third generation Mexican-Americans); Kessler-Harris \& Yans-McLaughlin, European Immigrant Groups, in Essays AND DAtA On AmERICAN Ethnic Groups 107, 110-115 (T. Sowell ed. 1978) (children of European immigrants have achieved greater occupational mobility than parents). Therefore, a first generation Mexican-American might offer statistical comparisons that use as benchmarks the "pass/fail" rate or work force representation of first generation Mexican-Americans rather than those of the broader, less homogeneous group of all Mexican-Americans.

Courts should proceed with caution here. Subgroup categories might be manipulated until a colorable claim of wrongful discrimination arises. With each opportunity to show adverse impact, the probability that some adverse impact can be shown is enhanced, even if that result is simply a product of sampling variation. Statistically significant results may arise by chance alone. See Shoben, supra note 37 , at $807 \& 820$. Courts should be alert to this problem. They might want to require a higher threshold of proof for a subgroup claim than for a national origin group claim. The Uniform Guidelines on Employee Selection Procedures presently embrace a " $4 / 5$ ths" rule: If the minority hiring rate is less than $4 / 5$ ths of the non-minority rate, adverse impact is deemed established. 29 C.F.R. $\S$ 1607.4(D) (1984).

51. Although the reporting of such statistics may raise privacy and fraud problems, these problems do not appear to be much more intractable than those that arise under the present rule requiring the reporting of national origin statistics. Moreover, the EEOC might investigate the possibility of employing additional safeguards to ensure that such data are recorded accurately and discreetly.

52. Such group subdivisions may cut the other way as well. A defendant-employer might rebut a plaintiff's statistical showing of an adverse impact upon the broad group of all Hispanics by pointing to the lack of an adverse impact upon the more assimilated group of Hispanics represented by the plaintiff. Of course, less assimilated Hispanics would still have a valid discrimination claim against the employer. Under Rule 23(c)(4)(B), "a class may be divided into subclasses and each subclass treated as a class." FED. R. CIV. P. 23. Occasionally, a subgroup might prefer not to make out a special claim in order to enhance group solidarity. Consideration of how a judge should decide whether to approve such a class under Rule 23 is beyond the scope of this Note. $C f$. Shoben, supra note 37, at 832 ("[T] he broad purpose of Title VII to eradicate discrimination . . . suggests a policy favoring large classes.") (footnote omitted).

53. Castro v. Beecher, 334 F. Supp. 930, 934 n.2 (D. Mass. 1971), affd in part, rev'd in part, 459 F.2d 725 (1st Cir. 1972). In defining a class of "Spanish-surnamed persons" for class certification under 42 U.S.C. $\S 1983$, the district court acknowledged the differences between persons such as " $a$ native American with a Spanish surname whose ancestors had for generations lived in the United States" and "persons who were born or whose parents were born in Puerto Rico, Cuba, or other Caribbean countries, whose primary language is Spanish, and who have not had education and training comparable to that received by most mainstream white Americans." 
Indeed, it is likely that there will be some overlap: Some Hispanics whose primary language is Spanish may be even more assimilated than their primarily English-speaking counterparts. Theoretically, since each individual represents a different degree of assimilation and therefore possesses a different vulnerability to discrimination, adverse impact should be determined solely with respect to the individual claimant. By its very nature, though, the disparate impact case turns on statistical comparisons of groups rather than individuals: Deviations from a group norm of assimilation are statistically unavoidable. ${ }^{54}$ The goal of the trait-based approach is simply to minimize those deviations, to the extent it is feasible, by providing for more than one norm within each national origin group. Courts should measure adverse impact upon as homogeneous a group as possible and scrutinize both claims and remedial decrees for their effect on identifiable national origin subgroups. ${ }^{\mathrm{s5}}$

\section{Trait-Based Discrimination in Soctal and Constitutional Context}

In fulfilling Title VII's goal of individual equality, the trait-based approach also accords with antidiscrimination principles, and promotes other important social and constitutional values.

\section{A. Eliminating Segregation and the Stigmatic Effects of Coercive Assimilation}

The current approach to national origin discrimination offers a choice between segregation and coercive assimilation. For the national origin

54. To the extent that the use of a subgroup minimizes the standard deviation from a group norm of assimilation, it provides a more effective mechanism of antidiscrimination enforcement. Of course, the deviations cannot be so great or widespread as to make meaningless a statistical showing of adverse impact. Using primary spoken language as a proxy makes such an occurrence unlikely, however, since that characteristic is itself an essential element of assimilation (or cultural independence, as the case may be).

55. The trait-based approach would also ensure a more equitable allocation of compensatory resources in court-approved consent decrees and court-ordered affirmative action programs. An employer found to have unlawfully discriminated on the basis of ancestral origin-i.e., against the broad group of Mexican-Americans-would not be able to redress that inequity through an affirmative action program that provided jobs only to the most assimilated Americans of Mexican descent. Nor would a judge be able to give his approval to a consent decree that was unresponsive to the claims of the least assimilated members of a national group. He might take particular care that the spectrum of assimilation was adequately represented in the membership of the national origin group's negotiating party.

Voluntary affirmative action plans might also be subject to trait-based scrutiny. A plan that set aside a certain number or percentage of positions for individuals of a particular national group might be considered unlawful if it discriminated against the least assimilated group members (such as those whose primary language was not English). 
group member whose distinctive ethnic and cultural traits are, for practical purposes, immutable, ${ }^{86}$ a promise of equality predicated upon their disappearance is a sham. It is like the promise made to a black child that he can attend a particular school if he sheds his black skin color. Each promise discriminates on the basis of irrelevant, immutable characteristics, contrary to the teaching of Brown v. Board of Education. ${ }^{57}$

Even where national origin-linked traits are not immutable, exclusion on that basis is antithetical to our notion of equality ${ }^{58}$ Brown's reliance upon the stigmatic harms of legally enforced separation ${ }^{59}$ suggests that exclusion on the basis of any national origin-linked characteristic should be impermissible. Forced assimilation, like segregation, may "generate a feeling of inferiority" group member that he must discard the characteristic manifestations of his national identity in order to have a truly equal and fair opportunity to compete for a job is to tell him that his identity has no place in American

56. See supra note 11.

57. 347 U.S. 483 (1954). See Fullilove v. Klutznick, 448 U.S. 448, 516 (1980) (Powell, J., concurring):

At least since [Brown], the Court has been resolute in its dedication to the principle that the Constitution envisions a Nation where race is irrelevant. The time cannot come too soon when no governmental decision will be based upon immutable characteristics of pigmentation or origin.

58. But see Garcia v. Gloor, 618 F.2d 264 (5th Cir. 1980) (employer can require bilingual employees to speak only English on the job), cert. denied, 449 U.S. 1113 (1981). The Fifth Circuit viewed Garcia's violation of the English-only rule as a "matter of choice," 618 F.2d at 270, and observed:

[T]he discriminations on which the Act focuses its laser of prohibition are those that are either beyond the victim's power to alter [i.e., immutable] . . . or that impose a burden . . . on one of the prohibited bases. No one can change his place of birth (national origin) [or] the place of birth of his forebears (national origin) .... 'But a hiring policy that distinguishes on some other ground . . . is related more closely to the employer's choice of how to run his business than to equality of employment opportunity.'

Id. at 269 (quoting Willingham v. Macon Tel. Publishing Co., 507 F.2d 1084, 1091 (5th Cir. 1975).

The court did note that "[c]ourts also have found discrimination in situations in which, although the basis of discrimination was not strictly immutable, a fundamental right was thought to be involved." 618 F.2d at 269 n.5 (citing Phillips v. Martin Marietta Corp., 400 U.S. 542 (1971) (employer may not refuse to hire women with pre-school age children absent business necessity); Sprogis v. United Air Lines, Inc., 444 F.2d 1194 (7th Cir. 1971) (rule prohibiting female stewardesses but not male stewards from getting married held discriminatory), cert. denied, 404 U.S. 991 (1971)). An assertion of cultural identity may involve just such a right-free expression and free exercise of religion under the First Amendment. See infra text accompanying note 67.

Garcia might also be distinguished on the basis of the district court's finding that the employer had several legitimate business reasons for enforcing the challenged rule, such as that it would better allow supervisors "to oversee the work of subordinates." 618 F.2d at 267.

59. See L. Tribe, American Constitutional LAw § 16-15, at 1021 (1978) (Brown sought to undo stigma contributing to stereotype of racial inferiority); Black, The Lawfulness of the Segregation Decisions, 69 YALE L.J. 421, 425 (1960) (state-imposed segregation coexists with rigid extralegal pattern of social intercourse designed to subordinate black race).

60. Brown v. Board of Educ., 347 U.S. 483, 494 (1954). 
society. ${ }^{61}$ Indeed, it is to exclude him from that society as long as he retains his ethnic identity. In sum, the reasoning which led the Court to strike down segregation in Brown also suggests the importance of the trait-based approach in protecting cultural identity as an element of equality.

\section{B. Promoting Cultural Pluralism}

The cultural pluralism ${ }^{62}$ that a trait-based approach to national origin discrimination would encourage is itself a value of social and constitutional significance. By allowing members of various nationalities to maintain, without penalty, their cultural heritage and identity ${ }^{63}$ the law nurtures a society richer in breadth and diversity-a society built upon the contributions and assets of the many rather than the few. ${ }^{84}$ Cultural pluralism has, in the last twenty years, surfaced as an important value for

61. As Justice Douglas once wrote of a school regulation which effectively prohibited Native Americans from wearing long, braided hair:

The results of such a policy . . . to force all students into one homogeneous mold even when it impinges on their racial and cultural values, have been disastrous for the young Indian child who is taught in school that the culture in which he has been reared is not important or valid.

New Rider v. Board of Educ., cert. denied, 414 U.S. 1097, 1102-03 (1973) (Douglas, J., dissenting from denial of certiorari) (emphasis added).

62. As used in this Note, "cultural pluralism" denotes that value which supports the right of a national group member to exercise the option of maintaining the culture and heritage that comprise his identity. The theory of cultural pluralism has its rcots in the work of Horace M. Kallen. See H. Kallen, Cultural Pluralism and the American Idea (1956); H. Kallen, Culture and Democracy in the United States (1924); Kallen, Democracy Versus the Melting-Pot (pts. 1 \& 2), 100 Natron 190, 217 (1915). Kallen conceived of cultural pluralism as being mandatory-individual rights were derived from, and were a function of, ethnic group membership. Subsequent social scientists have largely rejected this notion in favor of optional cultural pluralism, also called cultural democracy and democratic cultural pluralism. See M. Ramírez \& A. CAstañeda, Cultural Democracy, Biocognitive Development, And Education 24-28 (1974); Castan̂eda, Persisting Ideological Issues of Assimilation in America, in Cultural PluRalism 56, 60-62 (E. Epps ed. 1974); Comment, Cultural Pluralism, 13 Harv. G.R.-C.L. L. Rev. 133, 133 n.3, 136 n.17 (1978).

63. Of course, there is a limit to the amount of atomization which any society can withstand and still remain cohesive. This Note does not suggest that jobs must be defined without reference to business needs. "The touchstone," to borrow a phrase from the Supreme Court, "is business necessity" as presently conceived. Griggs v. Duke Power Co., 401 U.S. 424, 431 (1971).

64. See Kopan, Melting Pot: Myth or Reality?, in Cultural Pluralism, supra note 62, at 37, 54:

Cultural pluralism has given America its strength. Immigration has made the United States a world power of over 200 million people. The immigrants that came to America, both white and black, tilled the fields, manned the industries, built the railroads, and did many other things that made the country the industrial giant that it is. As its motto-E pluribus unum-proclaims, the United States remains truly one nation out of many people. 
many Americans, ${ }^{86}$ and ethnicity has become a focal point for political strength rather than an object of shame. ${ }^{68}$

That every individual is entitled to retain the distinctive ethnic traits that comprise his identity is a notion rooted in the Constitution's protections of individual liberty. First Amendment doctrine, in particular, supports the value of cultural pluralism. By explicitly protecting religion and speech from undue state intrusion, the First Amendment protects the primary components of culture. To the extent that culture takes either of those forms, cultural pluralism is afforded a constitutional safeguard. ${ }^{67}$

Of course, this pluralistic vision clashes with the pervasive image of the American melting pot. ${ }^{68}$ That paradigm envisions the assimilation of all newcomers into a singular American identity, from which cultural and ethnic differences have disappeared.

A tension between these two ideals-cultural pluralism on the one hand and assimilation on the other-is an inevitable outgrowth of the integrative efforts of a minority ethnic group that seeks also to preserve its distinct cultural identity. Almost by definition, integration involves assimilation. Yet achieving integration does not require a wholesale abandonment

65. See S. Steinberg, The Ethnic Myth: Race, Ethnicity, and Glass in America 3 (1981) ("The late 1960 s witnessed an outbreak of . . . 'ethnic fever."'); Comment, supra note 62, at 133.

66. See M. Novak, The Rise of the Unmeltable Ethnics 3-48 (1971) (describing ethnic assertion in 1970's and new ethnic politics); see also Bell, Ethnicity and Social Change, in ErHNicITY: Theory AND EXPERIEnCe 141 (N. Glazer \& D. Moynihan eds. 1975) ("In the last decade, there has been a resurgence of ethnic identification as the basis for effective political action in widely divergent societies.") (emphasis in original); Glazer \& Moynihan, Introduction, in id. at 25 (explaining that political mobilization has occurred along ethnic lines and that ethnic identity has become more "salient" in past twenty years).

67. As the Court noted in Tinker v. Des Moines Indep. Community School Dist., 393 U.S. 503 (1969), a case in which it struck down a school policy that prohibited students from wearing black armbands in protest of the Vietnam War, our constitutional system repudiates the idea that a state may conduct its schools to "foster a homogeneous people." Id. at 511 , quoting Meyer v. Nebraska, 262 U.S. 390, 402 (1923). But see New Rider v. Board of Educ., 480 F.2d 693 (10th Cir.) (rejecting claim by Pawnee Indian students that school regulation proscribing long hair violates their First and Fourteenth Amendment rights), cert. denied, 414 U.S. 1097 (1973). The Tenth Circuit's opinion reflects a certain doubt about the plaintiff's intention to communicate, as Pawnee Indians did not have a tradition of long hair length. 480 F.2d at 696; id. at 700 (Lewis, C.J., concurring). For a persuasive critique of the appellate court's opinion, see Comment, supra note 62 , at 140 . Justice Douglas, joined by Justice Marshall, dissented from the denial of certiorari, arguing that the case should be controlled by Tinker, and that the regulation violated the First Amendment rights of students attempting to communicate their pride in being Native Americans. 414 U.S. at 1099.

In Wisconsin v. Yoder, 406 U.S. 205 (1972), the Court addressed the issue of cultural homogeneity in the context of free exercise. Noting that school attendance beyond the eighth grade threatened the integrity of Amish traditions and beliefs, it held that mandatory post-eighth grade public schooling violated the First and Fourteenth Amendment rights of the Amish. Id. at 216-19.

68. The melting pot metaphor is more than two centuries old. "Here," wrote an American farmer in 1782, "individuals of all nations are melted into a new race of men . . . . J. CRÈvecoeur, LetTers From AN AMERICAN FArmer 39 (1957). Israel Zangwill's play, The Melting Pot, first performed in 1908, popularized the metaphor: "America is God's Crucible, the great Melting-Pot where all the races of Europe are melting and re-forming!" I. Zangwill, The Melting Pot 33 (1909). 
of cultural identity. "The melting pot is not designed to homogenize people, making them uniform in consistency. ... [Rather, it] depicts the wide diversities tolerated . . . under one flag." "69

Both the legislative and executive branches have at times recognized the value of (or at least the need to accommodate) cultural pluralism in American society. The Voting Rights Act Amendments of 1975 included a provision for bilingual elections ${ }^{70}$ in recognition of the diversity that characterizes the eligible voter population. The Bilingual Education Act of 1978 declared it to be the policy of the United States "to encourage the establishment and operation . . . of educational programs using bilingual educational practices, techniques, and methods" in recognition of the fact "that many . . . children . . . have a cultural heritage which differs from that of English-speaking persons." brace the pluralism ${ }^{72}$ of American society and afford it the protection of the trait-based approach in Title VII national origin cases.

\section{CONCLUSION}

Courts should respond to the ideal of individual equality articulated in Connecticut v. Teal and firmly rooted in Title VII and our notions of a just society, by adopting the trait-based approach in Title VII national origin cases. Only then might the employment opportunities available to unassimilated group members accord with those available to assimilated

69. Defunis v. Odegaard, 416 U.S. 312, 334 (1974) (Douglas, J., dissenting).

70. Voting Rights Amendments of 1975, Pub. L. No. 94-73, § 203, 89 Stat. 400, 402 (codified as amended at 42 U.S.C. $\$ 1973 a a-1 a(1982)$ ) (amending The Voting Rights Act of 1965, Pub. L. No. 89-110, 79 Stat. 437) (requiring provision of bilingual registration and voting notices, forms, instructions, assistance, ballots, etc., in states or political subdivisions where more than five percent of votingage citizens are members of single language minority with English literacy rate lower than national average).

71. Bilingual Education Act, Pub. L. No. 95-561, § 702(a), 92 Stat. 2268 (1978) (codified as amended at 20 U.S.C. $\S 3222$ (a) (1982)).

72. Bilingual education programs and bilingual election procedures arguably foster integration rather than pluralism. The intent of native language instruction may be simply to facilitate the minority student's understanding of, and transition to, the English language and American culture. Englishonly instruction may initially hinder his substantive development and ultimately isolate him from the larger community. In the same manner, an English-only ballot may totally alienate minority group citizens from the democratic process. The federal restrictions on English-only elections were spurred by a Congressional finding that "where State and local officials conduct elections only in English, language minority citizens are excluded from participating in the electoral process." 42 U.S.C. $\S$ $1973 \mathrm{~b}(\mathrm{I})(1)$ (1982) (emphasis added). This type of integration is not inconsistent with the goal of pluralism advocated in this Note. Using the trait-based approach to ensure equal job opportunity for even the least assimilated national group members may not only promote pluralism, but may also constitute the most effective means of accomplishing integration. The possession of a job may be an essential requirement of full "membership" in American society. This Note, like The Voting Rights Act Amendments and Bilingual Education Act, seeks an integration not predicated upon the abandonment of cultural identity. 


\section{National Origin Claims}

group members, and ultimately, with those available to Americans who trace their ancestry to the Mayflower.

-Stephen M. Cutler 